Jurnal Natural, Desember 2020. Vol 16. No 2 e-ISSN: 2746-427X, p-ISSN:1412-1328

\title{
UJI AKTIVITAS ANTIBAKTERI DAN SKRINING FITOKIMIA EKSTRAK HEKSANA, ETIL ASETAT DAN METANOL TUMBUHAN SURUHAN \\ (Peperomia pellucida L. Kunth)
}

\author{
Antibacterial Activity and Phytochemical Screening of Hexane, Ethyl Acetate and Methanol \\ Extracts of Suruhan Plant (Peperomia pellucida L. Kunth) \\ Restianti $^{*}$, Bimo Budi Santoso ${ }^{1}$, Maria Ludya Pulung ${ }^{1}$ \\ *E-mail: yanakaresta@gmail.com, ludya_chemistry@yahoo.com, restiantys@gmail.com
}

\begin{abstract}
ABSTRAK
Uji antibakteri dan skrining fitokimia ekstrak heksana, etil asetat dan metanol tumbuhan Suruhan terhadap bakteri E. coli dan $S$. aureus telah dilakukan. Ekstraksi terhadap tumbuhan Suruhan dilakukan dengan metode maserasi secara bertingkat berdasarkan tingkat kepolaran pelarut. Analisis kandungan senyawa kimia dilakukan dengan uji skrining fitokimia. Berdasarkan skrining fitokimia, ekstrak heksana dan etil asetat hanya terdeteksi adanya senyawa flavonoid dengan kategori sedang dan ekstrak metanol terdapat senyawa alkaloid dengan kategori kuat dan mengandung senyawa flavonoid dan tannin dengan kategori sedang. Hasil uji aktivitas antibakteri dengan metode difusi cakram menunjukkan bahwa ekstrak etil asetat dan metanol mempunyai aktivitas antibakteri dengan kategori kuat terhadap bakteri $S$. aureus yaitu masing-masing $14 \mathrm{~mm}$ dan $16 \mathrm{~mm}$. Ekstrak Heksana dan etil asetat mempunyai daya hambat yang kuat terhadap bakteri $E$. coli yaitu masing-masing $11 \mathrm{~mm}$ dan $12 \mathrm{~mm}$. Ekstrak methanol mempunyai daya hambat yang lemah terhadap bakteri E. coli yaitu $7 \mathrm{~mm}$, sedangkan ekstrak heksana mempunyai daya hambat lemah terhadap bakteri S. aureus yaitu 6 $\mathrm{mm}$.
\end{abstract}

KATA KUNCI: P. pellucida L. Kunth., Extract Heksana, Etil Asetat, Etanol, S. aureus , E. coli

\begin{abstract}
Antibacterial activity test and screening of phytochemical of extract hexane, ethyl acetate and methanol have been carried out. The extraction of the P.pellucida plants was carried out by the maceration method in stages based on the polarity of the solvent. Analysis of chemical compounds done with phytochemical screening test. Based on the identification of chemical compounds by phytochemical screening, hexane and ethyl acetate extract has been detected only in the presence of flavonoid compounds with moderate categories. Methanol extract contains high-grade alkaloids and moderate flavonoid and tannin compounds. Antibacterial test using disffusion methods suggest that ethyl acetate and methanol extract have categorically strong antibacterial activity againts the $S$. aureus of $14 \mathrm{~mm}$ and $16 \mathrm{~mm}$ respectively. Hexane extract and acetate ethyl have a strong inhibition to E. coli of $11 \mathrm{~mm}$ and $12 \mathrm{~mm}$ respectively. Methanol extract has a weak inhibition to bacteria E. coli and a hexane extract has a weak inhibition to bacteria $S$. aureus.
\end{abstract}

K EY WORDS: P. pellucida L. Kunth., Heksana, Etil Asetat, Etanol Extract, S. aureus, E. coli 


\section{PENDAHULUAN}

Provinsi Papua Barat adalah satu dari dua provinsi ditanah Papua. Dimana masih banyak penduduknya memanfaatkan tumbuhan di sekitarnya sebagai bahan obat untuk berbagai macam penyakit. Penelitian tumbuhan obat di tanah Papua masih relatif sedikit bahkan kecil terutama pada penelitian Etnobotani dan kandungan fitokimianya. Terlebih pulau Papua merupakan pulau dengan tingkat keanekaragaman hayati yang sangat tinggi, dan menyumbang sebagian besar keanekaragaman hayati di Indonesia. Tumbuhan obat adalah tumbuhan yang salah satu atau seluruh bagian pada tumbuhan tersebut mengandung zat aktif yang berkhasiat bagi kesehatan yang dapat dimanfaatkan sebagai penyembuh penyakit (Dalimarta, 2000; Wijayakusuma, 2008).

Salah satu tumbuhan obat yang dimanfaatkan untuk mengobati penyakit adalah tumbuhan suruhan atau P.pellucida L. Kunth. Yang mana masyarakat Kabupaten Manokwari memanfaatkan untuk mengobati asam urat dan menambah stamina. Tumbuhan ini dapat digunakan untuk mengobati beberapa penyakit seperti abses, bisul, jerawat, radang kulit, penyakit ginjal, sakit perut, asam urat, luka memar dan luka bakar ringan ( Wulandari Destik dan Desi Purwaningsih, 2016).

Wei et al. (2011) menyatakan, salah satu potensi tanaman suruhan adalah sebagai antimikroba. Senyawa-senyawa bioaktif sebagai antimikroba yang terkandung dalam suruhan perlu diuji lebih lanjut. Pengujian dilakukan untuk mengetahui kemampuan senyawa tersebut dalam menghambat dan membunuh bakteri.
Antibakteri merupakan zat yang dapat mengganggu pertumbuhan atau bahkan mematikan bakteri dengan cara mengganggu metabolisme mikroba yang merugikan. Mekanisme kerja dari antibakteri diantaranya yaitu menghambat sintesis dinding, menghambat keutuhan permeabilitas dinding sel bakteri, menghambat kerja enzim, dan menghambat sintesis asam nukleat dan protein (Dwidjoseputro, 1980).

\section{METODOLOGI PENELITIAN}

\section{Alat dan Bahan}

Alat-alat yang digunakan dalam penelitian ini adalah Erlenmeyer, timbangan analitik, seperangkat alat rotary Evaporator, botol, pipet volume, pipet tetes,mikropipet, alat ose, autoklaf, bunsen, seperangkat alatalat gelas ( tabung reaksi, gelas ukur 250 $\mathrm{mL}$, gelas piala $500 \mathrm{~mL}$ dan $100 \mathrm{~mL}$ ), corong, stirrer, hotplate, batang pengaduk, sudip, cawan petri dan thermometer.

Bahan-bahan yang digunakan dalam penelitian ini adalah :Tumbuhan suruhan, aquadest, methanol 70\%, n-heksana, etil asetat, $\mathrm{HCL}$ pekat, $\mathrm{H}_{2} \mathrm{SO}_{4}$ pekat, $\mathrm{NaOH} 1$ $\mathrm{M}, \mathrm{H}_{2} \mathrm{SO}_{4} 2 \mathrm{~N}$, pereaksi Mayer $\left(\mathrm{HgCl}_{2}\right.$ dan $\mathrm{KI}$ ), pereaksi Wagner (I2 dan KI), perekasi Lieberman Burchard ( asam asetat anhidrat dan $\mathrm{H}_{2} \mathrm{SO}_{4}$ pekat), $\mathrm{NaCl} 10 \%, \mathrm{FeCl}_{3} 1 \%$, pereaksi Dragondorff (bismuth nitrat), pereaksi Hager, NA (agar-agar, ekstrak beef, pepton, $\mathrm{NaCl}$ ), NB (pepton, ekstrak beef), strain murni E. coli dan S. aureus, dan kertas saring

\section{Prosedur Kerja}

\section{Preparasi Sampel}

Sampel tumbuhan Suruhan yang dikumpulkan dalam kantong plastic besar 
dicuci di bawah air yang mengalir sampai bersih. Setelah bersih, tumbuhan Suruhan ditiriskan, lalu dikeringkan dengan cara diangin-anginkan selama kurang lebih 1 minggu hingga kering. Kemudian dimasukan ke dalam oven dengan suhu 4050 C. Setelah kering, sampel dihaluskan dengan cara di tumbuk menggunakan mortar lalu di ayak hingga berbentuk serbuk

\section{Pembuatan Ekstrak}

Serbuk yang diperoleh kemudian
diekstraksi dengan metode maserasi menggunakan pelarut n-Heksana, Etil Asetat dan Metanol. Sebanyak 100 gr serbuk tumbuhan Suruhan ditambahkan n-Heksana sebanyak $250 \mathrm{~mL}$, diaduk menggunakan magnetic stirrer selama 3 jam pada suhu kamar dan didiamkan selama 24 jam. Setelah itu disaring sehingga diperoleh filtrate 1 fraksi n-Heksana. Selanjutnya residu yang dihasilkan diekstrak kembali menggunakan n-Heksana dengan perlakuan yang sama sampai diperoleh filtrate 2 dan 3 frakasi n-Heksana. Setelah dilakukan ekstraksi menggunakan pelarut n-Heksana selanjutnya dilakukan ekstrksi menggunakan pelarut Etil Asetat dan Metanol terhadap residu serbuk daun suruhan dengan perlakukan yang sama terhadap ekstraksi nHeksana hingga diperoleh 3 filtrat fraksi Etil Asetat dan 3 filtrat fraksi Metanol. Setelah itu filtrate dari masing-masing fraksi dipekatkan dengan rotary evaporator hingga diperoleh ekstrak kental dan selanjutnya akan diuji fitokimia dan uji antibakteri.

\section{Uji Fitokimia}

Sebelum melakukan isolasi tehadap suatu kandungan kimia yang diinginkan dalam suatu tumbuhan maka perlu dilakukan indentifikasi pendahuluan kandungan senyawa metabolit sekunder yang ada pada masing-masing tumbuhan, sehingga dapat diketahui kandungan senyawa yang ada pada tumbuhan tersebut (Darwis, 2000:4).

\section{Uji aktivitas Antibakteri Ekstrak}

Pembuatan Biakan

Strain murni Escherichia coli dan Staphylococcus aureus, disuspensikan pada media Nutrient Broth (NB), lalu media diinkubasi pada suhu $37^{\circ} \mathrm{C}$ selama 24 jam. Selanjutnya bakteri E.coli ditanamkan pada media Nutrient Agar (NA) pada suhu $37^{\circ} \mathrm{C}$ selama 24 jam. Satu ose koloni bakteri diambil dari NA disuspensikan kedalam tabung berisi $1 \mathrm{~mL}$ media $\mathrm{NB}$ dan diinkubasi pada suhu $37^{\circ} \mathrm{C}$ selama 24 jam.

Pembuatan Media

Untuk pembuatan media Nutrient Agar (NA): Ekstrak beef $10 \mathrm{~g}$, pepton $10 \mathrm{~g}$ $\mathrm{NaCl} 5 \mathrm{~g}$, air distilasi $500 \mathrm{~mL}$, dan $20 \mathrm{~g}$ agar/L. Agar dilarutkan dengan komposisi lain dan disterilisasi dengan autoklaf pada $121^{\circ} \mathrm{C}$ selama 15 menit. Kemudian siapkan wadah yang dibutuhkan.

Untuk pembuatan Nutrient Broth (NB): Larutkan 5 gram pepton dalam 200 $\mathrm{mL}$ air distilasi/aquades setelah dilarutkan 3 gram ekstrak daging dalam larutannya. Atur $\mathrm{pH}$ sampai 7,0 tambahkan air destilasi sebanyak $200 \mathrm{~mL}$ dan disterilisasi dengan autoklaf.

Uji Aktivitas Antibakteri (Difusi Agar Kirby Bauer)

Penyiapan media padat yang berisi bakteri dilakukan dengan cara menuangkan $20 \mathrm{~mL}$ Nutrient Agar (NA) cair yang temperaturnya $40-45^{\circ} \mathrm{C}$ dan membiarkannya membeku. Setelah membeku, dipipet sekitar 0,4 mL, suspensi bakteri kedalam cawan petri steril yang telah berisi media Nutrient Agar (NA) padat dan dispreader sampai rata. 
Setelah itu kertas cakram direndam dengan masing-masing ekstrak, kemudian diletakkan dipermukaan agar dan diinkubasi pada suhu $37^{\circ} \mathrm{C}$ selama 24 jam, sebagai kontrol negatif digunakan pelarut dari masing-masing ekstrak dan akan dibandingkan juga dengan kontrol positif yaitu antibiotik kloramfenikol. Dalam hal ini, hasil positif ditandai dengan terbentuknya daerah bening pada sekitar kartas cakram yang menunjukkan adanya penghambatan pertumbuhan bakteri. Ekstrak yang zona beningnya paling besar dianggap sebagai ekstrak yang paling aktif antibakteri.

Aktivitas antimikroba dilihat dengan mengukur diameter zona hambat yang diamati, yang ditandai dengan terbentukknya zona bening disekitar kertas cakram tersebut.

Analisis Data

Data hasil skrining fitokimia, pengujian antibakteri yang diperoleh akan dianalisis secara deskriptif.

\section{Hasil dan Pembahasan Ekstrkasi}

Sebanyak 100 gr bubuk sari Suruhan ditimbang dan diekstraksi secara berturutturut menggunakan pelarut n-heksana, etilasetat dan methanol. Ekstraksi dengan cara ini merupakan ekstraksi bertingkat berdasarkan sifat polaritas pelarut yang dilakukan secara bertahap dari non-polar, semipolar dan polar. Hal ini dilakukan untuk mendapatkan ekstrak yang dapat dibedakan tingkat kepolarannya sehingga diperoleh komponen yang lebih murni dan tidak bercampur.

\section{Hasil Uji Fitokimia Ekstrak Heksana, Etil Asetat dan Metanol}

Uji fitokimia dilakukan dengan tujuan untuk mengetahui kandungan metabolit sekunder bubuk Suruhan hasil ekstraksi bertingkat, yakni ekstrak nheksana, etil asetat dan metanol. Ekstrak heksana dan etil asetat memberikan uji positif sedang pada uji flavonoid dan ekstrak metanol memberikan uji positif sedang pada uji alkaloid, positif kuat pada uji flavonoid dan positif sedang pada uji tannin.

Tabel 4.1 Hasil uji fitokimia ekstrak heksana, etilasetat dan metanol

\begin{tabular}{lccc}
\hline \multicolumn{1}{c}{ Uji } & \multicolumn{3}{c}{ Jenis Sampel } \\
Fitokimia & Heksana & Etil Asetat & Metanol \\
\hline Alkaloid & - & - & ++ \\
Flavonoid & ++ & ++ & ++ \\
Saponin & - & - & - \\
Tannin & - & - & ++ \\
\hline Keterangan: & - & : Negatif & \\
& + & : Positif lemah & \\
& ++ & : Positif sedang \\
& +++ & : Positif kuat \\
& +++ & : Positif sangat kuat
\end{tabular}

\section{Uji Aktivitas Antibakteri}

Uji aktivitas antibakteri pada penelitian ini dilakukan dengan metode difusi cakram. Prinsip dari metode ini adalah terdifusinya zat antibakteri yang berada pada kertas cakram menuju permukaan media agar yang telah diinokubasi atau ditanami bakteri uji. Bakteri akan terhambat pertumbuhannya dengan pengamatan terbentuknya zona bening disekeliling kertas cakram. Pengujian ini dilakukan terhadap bakteri $S$. aureus (gram positif) dan bakteri E. coli (gram negatif).

Diameter zona bening yang muncul di sekitar cakram berisi ekstrak heksana, ekstrak etil asetat dan ekstrak metanol dibandingkan dengan diameter zona bening yang muncul di sekitar cakram yang berisi kontrol positif(kloramfenikol) dan kontrol negatif(pelarut). 
Tabel 4.2 Diameter Zona Hambat Ekstrak Heksana, Etil asetat dan Metanol

\begin{tabular}{|c|c|c|c|c|}
\hline \multirow[b]{2}{*}{ Bakteri } & \multicolumn{4}{|c|}{ Diameter zona bening } \\
\hline & Ekstrak & $\begin{array}{l}\text { Rata- } \\
\text { rata }\end{array}$ & $\begin{array}{l}\text { Kontrol } \\
\text { positif }\end{array}$ & $\begin{array}{l}\text { Kontrol } \\
\text { negatif }\end{array}$ \\
\hline \multirow{4}{*}{ E. coli } & Heksana & $\begin{array}{l}11 \\
\mathrm{~mm}\end{array}$ & $9 \mathrm{~mm}$ & $4 \mathrm{~mm}$ \\
\hline & $\begin{array}{l}\text { Etil } \\
\text { asetat }\end{array}$ & $\begin{array}{l}12 \\
\mathrm{~mm}\end{array}$ & $17 \mathrm{~mm}$ & $4 \mathrm{~mm}$ \\
\hline & Metanol & $6 \mathrm{~mm}$ & $16 \mathrm{~mm}$ & $4 \mathrm{~mm}$ \\
\hline & Heksana & $7 \mathrm{~mm}$ & $17 \mathrm{~mm}$ & $4 \mathrm{~mm}$ \\
\hline \multirow{2}{*}{$\begin{array}{c}S . \\
\text { aureus }\end{array}$} & $\begin{array}{l}\text { Etil } \\
\text { asetat }\end{array}$ & $\begin{array}{l}14 \\
\mathrm{~mm}\end{array}$ & $15 \mathrm{~mm}$ & $7 \mathrm{~mm}$ \\
\hline & Metanol & $\begin{array}{c}16 \\
\mathrm{~mm}\end{array}$ & $11 \mathrm{~mm}$ & $4 \mathrm{~mm}$ \\
\hline
\end{tabular}

Pengujian dilakukan inokulasi 48 jam, hasil pengamatan zona bening ekstrak heksan, etil asetat dan metanol tumbuhan Suruhan dapat dilihat pada Gambar 4.12. Hasil uji terhadap bakteri E. coli ekstrak heksan menunjukkan rata-rata zona hambat $11,00 \mathrm{~mm}$. Ekstrak etil asetat menunjukkan rata-rata zona hambat $12,00 \mathrm{~mm}$. Kemudian ekstrak metanol menunjukkan rata-rata zona hambat $6,00 \mathrm{~mm}$. Sedangkan terhadap bakteri $S$. aureus ekstrak heksan menunjukkan rata-rata zona hambat 7,00 $\mathrm{mm}$. Ekstrak etil asetat menunjukkan ratarata zona hambat $14,00 \mathrm{~mm}$, sedangkan ekstrak metanol menunjukkan rata-rata zona hambat $16,00 \mathrm{~mm}$.
Tabel 4.3 Kategori zona hambat ekstrak Tumbuhan Suruhan

-

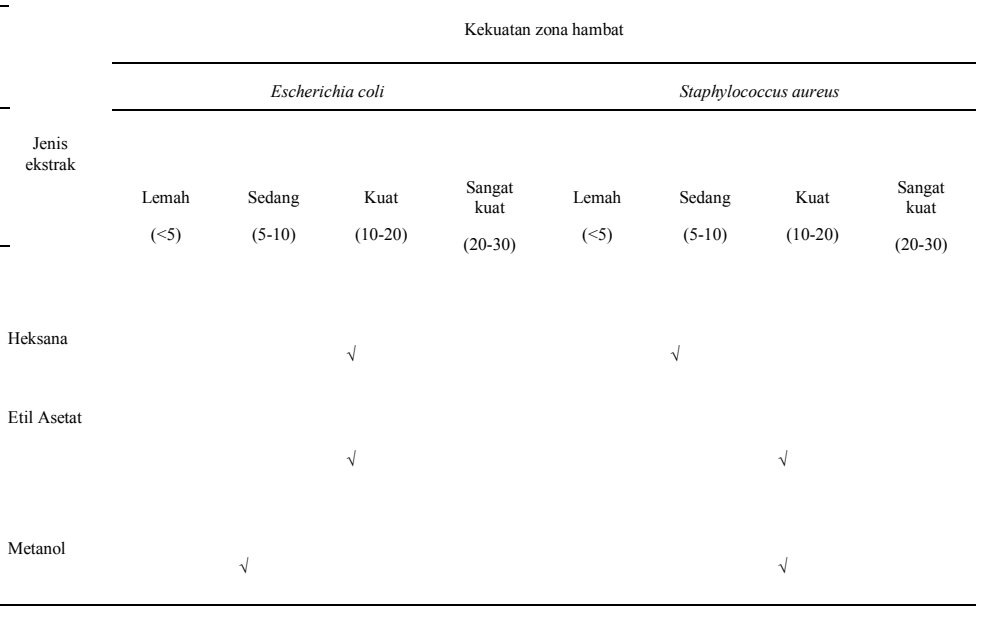

Berdasarkan katagori yang seperti ditunjukkan pada Tabel 4.3, Ekstrak heksana mempunyai sifat antibakteri yang kuat terhadap bakteri $E$. coli dan potensi yang sedang terhadap bakteri $S$. aureus, bahkan pada bakteri E. coli daya hambat ekstrak heksana lebih besar dari pada kontrol positif, ekstrak metanol mempunyai aktivitas antibakteri yang sedang terhadap bakteri $E$. coli dan aktivitas yang kuat terhadap bakteri S. aureus, dan juga mempunyai daya hambat lebih besar dari pada kontrol positif. Sedangkan ekstrak etil asetat mempunyai sifat antibakteri yang kuat terhadap kedua bakteri. Adanya suatu perbedaan daya hambat dari masing- masing ekstrak tumbuhan Suruhan terhadap masing-masing bakteri dapat disebabkan perbedaan struktur dan komposisi sel masing-masing bakteri (Priya et al., 2010). Perbedaan jenis dan jumlah senyawa kimia yang terkandung pada tiap ekstrak tumbuhan $P$. pellucida dapat juga mempengaruhi daya penghambatannya terhadap bakteri. 
Komponen senyawa yang berbeda dapat menghasilkan efek antibakteri yang berbeda pula. Hasil uji penapisan fitokimia menunjukkan ekstrak metanol mempunyai kandungan senyawa alkaloid, flavonoid dan tannin sedangkan ekstrak heksana dan etil asetat mengandung senyawa flavonoid.

Okeke et all (2001) dan Rahman et all (2010) menyebutkan bahwa beberapa senyawa metabolit sekunder seperti glikosida, saponin, tannin, flavonoid, terpenoid, dan alkaloid telah dilaporkan mempunyai aktivitas antibakteri. Quercetin, salah satu senyawa turunan golongan flavonoid dapat menghambat pertumbuhan bakteri Staphylococcus aureus (Bimlesh Kumar et all, 2011) sedangkan Indoquinolin dari Cryptolepsis sanguinolenta mempunyai aktivitas antibakteri terhadap bakteri gram negative dan kapang (Silva et all, 1996). Tanaman menyintesis senyawa flavon, flavonoid dan flavonol untuk merespon infeksi microbial (Ncube et all, 2008). Anyasor et all (2011) menyatakan bahwa aktivitas antibakteri dari ekstrak tanaman kemungkinan disebabkan oleh adanya senyawa tannin dan flavonoid yang berikatan dengan dinding sel bakteri dan menghambat biosintesisnya.

Secara umum daya hambat terhadap bakteri uji, Ketiga ekstrak tumbuhan Suruhan lebih sensitif terhadap bakteri $S$. aureus daripada E. coli. Hal ini diduga karena perbedaan susunan dinding sel bakteri dimana bakteri $E$. coli mempunyai lapisan dinding sel yang lebih kompleks dibandingkan $S$. aureus (Natheer et all, 2012), sehingga lebih sulit untuk dirusak oleh senyawa-senyawa kimia yang terdapat pada ketiga jenis ekstrak $P$. pellucida.

\section{KESIMPULAN}

Berdasarkan ekstraksi bertingkat tumbuhan Suruhan (P. pellucida L. Kunth) diperoleh ekstrak kental dari masingmasing pelarut. Kandungan fitokimia yang teridentifikasi dalam ekstrak heksana dan etil asetat yaitu flavonoid dengan katagori sedang. Ekstrak methanol mengandung flavonoid dan tannin dengan kadar sedang dan mengandung alkaloid dengan kategori kuat.

Uji aktivitas antibakteri dengan metode difusi cakram dari masing-masing ektrak tumbuhan $P$. pellucida, secara umum menunjukkan bahwa ketiga ekstrak mempunyai sifat antibakteri kategori sedang dan kuat. Dimana ekstrak heksana memiliki diameter zona hambat terhadap bakteri $S$. aureus yaitu $7 \mathrm{~mm}$ dan $11 \mathrm{~mm}$ terhadap bakteri E. coli. Ekstrak etil asetat memiliki diameter zona hambat $12 \mathrm{~mm}$ terhadap bakteri $E$. coli dan $14 \mathrm{~mm}$ terhadap bakteri $S$. aureus. Ekstrak metanol memiliki diameter zona hambat $16 \mathrm{~mm}$ terhadap bakteri $S$. aureus; dan diameter zona hambat $6 \mathrm{~mm}$ terhadap bakteri E. coli. Dari ketiga ekstrak tersebut, ekstrak methanol dan etil asetat mempunyai potensi yang cukup baik sebagai antibakteri, khususnya terhadap bakteri $S$. aureus. Secara umum ketiga ekstrak mempunyai sifat antibakteri yang lebih kuat terhadap bakteri $S$. aureus dibandingan terhadap bakteri $E$, coli. 


\section{Daftar Pustaka}

Anyasor GN, Aina DA, Olushola M, Aniyikaya AF (2011). Phytochemical constituent, proximate analysis, antioxidant, antibacterial and wound healing properties of leaf extracts of Chromoleana odotera. Ann. Biol. Res.,2:441-451

Bimlesh Kumar, Harleen Kaur Sandhar, Sunil Prasher, Prashant Tiwari, Manoj Sakhan, Pardeep Sharma. 2011. A Review of Phytochemistry and Pharmacological of Flavonoids. International Pharmaceutica Sciencia

Dalimarta, S.2006. Atlas Tumbuhan Obat Indonesia Jilid 4. Puspaswara, Jakarta

Dalimarta, S.2000. Atlas Tumbuhan Obat Indonesia Jilid 2. Jakarta: Trubus Agriwidya

Darwis, D. Teknik Dasar Laboratorium Dalam Penelitian Senyawa Bahan Alam Hayati. Padang:FMIPA Universitas Andalas, 2000

Natheer, S.E., Sekar., P. Amutharaj., M. Syed Abdul Rahman and K. Keroz Khan. 2012. Evolution of Antibacterial Activity of Morinda citrifolia, Vitex trifolia and Chromoleana odorata. African journal of Pharmacy and Pharmacology Vol. 6 (11), pp. 783788

Ncube, NS, Afolayan AJ, Okoh AI. Assesment Technique of Antimicrobial Properties of Natural Compounds of Plant Origin: Current Methods and
Future Trends. African journal of Biotechnology 2008;7 (12):1797-1806

Okeke MI, Iroegbu CU, Eze EN, Okali AS, Esimone CO (2001). Evolution of extracts of the root of Landolphia owerrience for antibacterial activity. $J$. Ethnopharmacol., 78:119-127

Priya V, Mallika J, Surapaneni KM, Saraswathi P, Chandra SG. 2010. Antimicrobial activity of pericarp extract of Garcinia mangostana Linn. International Journal of Pharma Sciences and Research. 1(8) :278-281.

Rahman MA, Ahsna T, Islam S. (2010). Antibacterial and antifungal properties of methanol extracts from the stem of Argyreia argentea. Bang. J. Pharmacol., 5:41-44

Silva, O., Duarte A, Cabrita J, Pimentel M, Diniz A and Gomez E. 1996. Antibacterial Activity of GuineaBissua Traditional Remedies. $J$. Enthnopharmacol. 50:53-59

Wei, L.S., W. Wee, J.Y.F. Siong, \& D.F. Syamsumir. 2011. Characterization of Anticancer, Antimicrobial, Antioxidant Properties and Chemical Compositions of Peperomia pellucida Leaf Extrac. Acta Medica Iranica 49(10):670-674.

Wulandari Destik dan Desi Purwaningsih. 2016. Uji Aktivitas Antibakteri Ekstrak Etanol Daun Suruhan (Peperomia pellucida [L]. Kunth) terhadap bakteri Shigella dysentriae, Universitas Setia Budi: Surakarta. 